\title{
Severe anemia and adverse pregnancy outcome in a tertiary care hospital in North India
}

\author{
Premlata Yadav* \\ Department of Obstetrics and Gynecology, Rajendra Institute of Medical Sciences, Ranchi, Jharkhand, India
}

Received: 19 October 2017

Accepted: 11 December 2017

\section{*Correspondence:}

Dr. Premlata Yadav,

E-mail: drpremlata1307@gmail.com

Copyright: (C) the author(s), publisher and licensee Medip Academy. This is an open-access article distributed under the terms of the Creative Commons Attribution Non-Commercial License, which permits unrestricted non-commercial use, distribution, and reproduction in any medium, provided the original work is properly cited.

\begin{abstract}
Background: Anaemia is commonest medical disorder in pregnancy with $88 \%$ prevalence in India mainly due to ignorance, poverty and gender bias. 40-60\% of maternal deaths in developing countries. According to the recent standard laid down by WHO anemia is present when the hemoglobin $(\mathrm{Hb})$ concentration in the peripheral blood is less than $11 \mathrm{gm} / \mathrm{dl}$. The most common cause of anemia in pregnancy is iron deficiency. Anemia is diagnosed by estimating the hemoglobin concentration and examining a peripheral blood smear for the characteristic red blood cell changes. The aim of the study was to determine the association between severe anemia, maternal and perinatal complications.

Methods: Case control study was done in department of Obstetrics and Gynecology, Rajendra Institute of Medical Sciences Ranchi, India from February 2016 to July 2016. 100 pregnant women, admitted for delivery and having severe anemia were studied and compared with 100 non-anaemic women of similar demographic features. Maternal and perinatal complications were observed. Pearson, chi-square and Fischer exact tests were used to calculate significance of results.

Results: Of the severely anaemic mothers, $36 \%$ babies were low birth weight $(\mathrm{p}=0.042)$ and $20 \%$ were small for gestational age $(\mathrm{p}=0.026)$, as compared to $18 \%$ and $10 \%$ of controls, respectively.

Conclusions: Severe maternal anemia carries significant risk of hemorrhage and infection in the mother. It is also associated with preterm birth, low birth weight.
\end{abstract}

Keywords: Severe anemia, Pregnancy outcomes

\section{INTRODUCTION}

Anaemia is the most common nutritional deficiency disorder in the world. In India anaemia antedates pregnancy, is aggravated by increased requirements during pregnancy and blood loss at delivery, infections in the antenatal and postnatal periods, and the early advent of next pregnancy perpetuates it. ${ }^{1}$ It causes direct as well as indirect deaths from cardiac failure, hemorrhage, infection and preeclampsia. ${ }^{2}$
Women go through a variety of physiological changes during pregnancy. Changes in the blood circulatory system are particularly notable, permitting normal fetal growth. Even in normal pregnant women, the hemoglobin concentration decreases with dilution according to the increase in the volume of circulating blood. Anemia is commonest medical disorder in pregnancy with $88 \%$ prevalence in India mainly due to ignorance, poverty and gender bias. $40-60 \%$ of maternal death in developing countries. $^{3}$ 
Pregnant women with significant anemia may have an increased risk for poor pregnancy outcomes, particularly if they are anemic in the first trimester. ${ }^{4}$ It carries a lot of threats to the mother as well as baby. ${ }^{5}$

Studies have shown that iron deficiency is the major cause of anaemia followed by folate deficiency. In recent years, the contribution of Vitamin B12 deficiency has been highlighted. ${ }^{6}$ Data are inadequate to determine the extent to which maternal anemia might contribute to maternal mortality. ${ }^{7}$

Anaemia is very often asymptomatic in pregnancy, with the diagnosis being made on routine screening. ${ }^{8}$ It is defined by WHO as hemoglobin level less than 11 grams $\%$ in pregnancy. It is divided into three degrees

- $\quad$ Mild degree (9.0-10.9 gm\%),

- Moderate degree (7.0-8.9 gm\%) and

- Severe degree $(<7.0 \mathrm{gm} \%)$.

Current knowledge indicates that iron deficiency anemia in pregnancy is a risk factor for preterm delivery and subsequent low birth weight, and possibly for inferior neonatal health. ${ }^{9}$

This deserves further exploration because of the tendency of infants to develop complications. The aim of the study was to determine the association between severe anemia, maternal and perinatal complications.

\section{METHODS}

Case-control study was done at Department of Obstetrics and Gynecology, RIMS, Ranchi, India from February 2016 to July 2016. Study population of 200 (100 cases and 100 controls) were taken for the study.

All patients admitted for delivery with $\mathrm{hb} \%<7 \mathrm{~g} / \mathrm{dl}$ were taken as inclusion criteria. Population having mild and moderate anemia (8-10 g/d), K/c/o hemogobinopathes like thalesemia, antipartum hemorrhage due to placenta previa, hemolytic anemia like SCD were excluded from the study.

100 pregnant women, admitted for delivery, having severe anemia were studied and compared with 100 nonanemic women of similar demographic features.

Detailed clinical history and menstrual history of the entire patient was taken. Thorough general and systemic examination of the patient was recorded.

All the routine investigation along with CBC, S. Ferritin, and Peripheral blood smear examination were done. Follow up of these patients was done for foetomaternal outcome. Maternal and perinatal complications were observed, pearson, chi-square and fischer exact tests were used to calculate significance of results.

\section{RESULTS}

There were 3040 deliveries at RIMS Ranchi, India. 2037 $(67 \%)$ women had anaemia and 107 (3.5\%) had severe anemia.

Table 1: Characteristics of cases and controls of patients.

\begin{tabular}{|lll|}
\hline Characteristics & Cases & Controls \\
\hline Booked & 24 & 64 \\
\hline Unbooked & 76 & 36 \\
\hline Emergency admission & 80 & 52 \\
\hline OPD admission & 20 & 48 \\
\hline$<20$ years & 14 & 10 \\
\hline$>20$ years & 86 & 90 \\
\hline Primigravida & 34 & 48 \\
\hline Multigravida & 66 & 52 \\
\hline Gestational age $<37$ weeks & 34 & 16 \\
\hline Gestational age $>37$ weeks & 66 & 84 \\
\hline Mean Hb\% & $6.2 \pm 0.6$ & $11.6 \pm 0.6$ \\
\hline Mean blood loss & $427 \pm 386$ & $252 \pm 128$ \\
\hline Blood transfusion $<5$ points & 66 & 2 \\
\hline Blood transfusion $1-5$ points & 34 & 0 \\
\hline No blood transfusion & 0 & 98 \\
\hline Hospitalization $<8$ days & 52 & 84 \\
\hline Hospitalization $>8$ days & 48 & 16 \\
\hline
\end{tabular}

In the present study the proportion of cases were more among unbooked women (76\%), emergency admission (80\%), multigravida (66\%). Most of the patients $(86 \%)$ with anemia belonged to the age group more than 20 years of age. Majority of women $(66 \%)$ with anemia belonged to gestational age more than 37 weeks. Need of blood transfusion was more among cases as compared to controls. Blood transfusion was done in $100 \%$ cases as compared to only $2 \%$ controls needed blood transfusion. The mean hemoglobin in anemic patients was $6.2 \mathrm{~g} \%$ which was significantly less as compared to the control group that was $11.6 \mathrm{~g} \%$. Duration of hospital stay of cases was more than controls. The duration of hospital stay was less than 8 days in $84 \%$ controls as compared to $56 \%$ cases while hospital stay was more than 8 days in $48 \%$ cases as compared to $16 \%$ in controls. Blood loss was higher in cases as compared to the controls. Blood loss was $427 \mathrm{ml}$ in cases that was significantly more than that of controls that was $252 \mathrm{ml}$.

Table 2: Distribution of cases according to PBF examination.

\begin{tabular}{|lll}
\hline PBF & Cases & Controls \\
\hline Dimorphic & $8 \%$ & 0 \\
\hline Macrocytic hypochromic & $10 \%$ & 0 \\
\hline Microcytic hypochromic & $80 \%$ & 0 \\
\hline Normocytic normochromic & $2 \%$ & $100 \%$ \\
\hline
\end{tabular}

The most common type of anemia in the cases was microcytic hypochromic $(80 \%)$ followed by macrocytic 
hypochromic anemia (10\%). The only type of anemia present in the control group was normocytic normochromic anemia.

Table 3: Maternal complications.

\begin{tabular}{|llllll|}
\hline $\begin{array}{l}\text { Complications } \\
\text { Abruption }\end{array}$ & Cases & $\%$ & Controls & $\%$ & $\begin{array}{l}\text { P - } \\
\text { value }\end{array}$ \\
placenta & 10 & 10 & 6 & 6 & 0.712 \\
\hline Wound infection & 18 & 18 & 2 & 2 & 0.02 \\
\hline Preeclampsia & 20 & 20 & 10 & 10 & 0.026 \\
\hline Sepsis & 10 & 10 & 0 & 0 & 0.01 \\
\hline CHF & 4 & 4 & 0 & 0 & 0.036 \\
\hline $\begin{array}{l}\text { Post-partum } \\
\text { haemorrhage }\end{array}$ & 34 & 34 & 4 & 4 & 0.001 \\
\hline $\begin{array}{l}\text { Maternal } \\
\text { morbidity }\end{array}$ & 48 & 48 & 10 & 10 & 0.024 \\
\hline Maternal death & 8 & 8 & 0 & 0 & 0.126 \\
\hline
\end{tabular}

Placental abruption was more common in patients of anemia (10\%) than in controls but that was not statistically significant. Almost all the complications were more common in anemic patients. Post-partum hemorrhage occurred in 34\% (34) of cases as compared to $4 \%$ (4) of controls ( $\mathrm{p}=0.001)$ and this was statistically significant. Frequency of infection of surgical wound was significantly more in $10 \%$ (10) in cases as compared to $2 \%(2)$ in controls $(\mathrm{p}=0.002)$ and this is also statistically significant. Sepsis and CHF were significantly more in cases as compared to controls and were statistically significant. Preeclampsia is more common among anemic patients $(20 \% \mathrm{v} / \mathrm{s} 10 \%)$. Maternal morbidity was $48 \%$ (48) that was significantly higher in cases as compared to controls $(10 \%)$ this is also statistically significant. Maternal mortality was more among cases $(8 \%)$ but no mortality was observed in controls.

Table 4: Perinatal complications.

\begin{tabular}{|llllll|}
\hline $\begin{array}{l}\text { Complications } \\
\text { Low birth }\end{array}$ & Cases & $\%$ & Controls & $\%$ & $\begin{array}{l}\text { P- } \\
\text { value }\end{array}$ \\
$\begin{array}{l}\text { weight infant } \\
\text { Preterm birth }\end{array}$ & 36 & 36 & 18 & 18 & 0.042 \\
\hline IUGR & 20 & 20 & 10 & 10 & 0.036 \\
\hline $\begin{array}{l}\text { APGAR score } \\
\text { < } 7\end{array}$ & 8 & 8 & 4 & 4 & 0.67 \\
\hline In-utero death & 2 & 2 & 4 & 4 & 1 \\
\hline Perinatal death & 4 & 4 & 0 & 0 & 0.036 \\
\hline
\end{tabular}

Preterm birth was approximately 2 times more common in cases as compared to controls and is statistically significant. Preterm birth was seen in 34\% (34) cases and $16 \%$ (16) controls ( $\mathrm{p}=0.036)$. Low birth babies and IUGR were 2 times more common in cases as compared to controls and was statistically significant. Of the severely anemic mothers, 36\% (36) babies were low birth weight $(\mathrm{p}=0.042)$ and $20 \%(20)$ were IUGR $(\mathrm{p}=0.026)$, as compared to $18 \%$ and $10 \%$ of controls, respectively. Perinatal death was seen in $4 \%$ (4) cases and none in controls $(p=0.036)$.

\section{DISCUSSION}

Levy A et al concluded that the incidence of asphyxia $(40 \%)$ and intrauterine growth retardation (38\%) were significantly higher in anemic group as compared to normal haemoglobin. ${ }^{10}$

Kavle JA et al, found strong association of severe anemia with post-partum hemorrhage. Wandabwa $\mathrm{J}$ et al has also indicated chronic anemia as a predictor for postpartumhemorrhage. ${ }^{11}$

Karaflahin E, et al studied association between maternal anaemia and perinatal outcome at Gulhane Military Medical Academy, Department of Obstetrics and Gynecology, Ankara. ${ }^{12}$

Ali AAA, et al conducted retrospective case-control study at Kassala hospital, eastern Sudan. pregnant women with severe anemia $(\mathrm{Hb})<7 \mathrm{~g} / \mathrm{dl}, \mathrm{n}=303$, who delivered from January 2008 to December 2010 with 2.3 times risk of LBW, 3.4 times risk of preterm, 4.3 times risk stillborns, concluded as greater the severity of the anaemia during pregnancy, the greater the risk of preeclampsia, preterm delivery, LBW and stillbirth. ${ }^{13}$

Abdel A et al concluded that the corrected risk for preeclampsia with severe anaemia was more $(\mathrm{OR}=$ 3.6,95\% CI:1.4-9.1, P = 0.007) as compared with women with no anaemia. ${ }^{14}$

Ghimire et al concluded that the frequency of low birth weight and Apgar score $<7 / 10$ at birth was more in anemic group and the difference was statistically significant. Preeti $\mathbf{J}$ et al found a significant correlation between anaemia and development of preeclampsia, eclampsia, and preterm labour $(\mathrm{P}$ value $<0.05) .{ }^{15}$

\section{CONCLUSION}

Severe maternal anaemia caries significant risk of hemorrhage, infection, morbidity and mortality in mother. It also associated with preterm birth, low birth weight and perinatal mortality.

Funding: No funding sources

Conflict of interest: None declared

Ethical approval: The study was approved by the Institutional Ethics Committee

\section{REFERENCES}

1. Prema K, Neela KS, Ramlakshmi BA. Anaemia and adverse obstetric outcome. Nutr Rep Int. 1981;23:637-43. 
2. Sarin AR. Severe anemia in pregnancy, recent experience. Int J Gynecology Obstet. 1995;50:45-9.

3. World Health Organization. WHO Global Database. Geneva: WHO; 1997.

4. Bhatt R. Maternal mortality in India-FOGSI-WHO Study. J Obstet Gynecol Ind. 1997;47:207-14.

5. Brabin L, Nicholas S, Gogate A, Karande A. A high prevalence of anemia among women in Mumbai, India. Food Nutr Bull. 1998;19:205-9.

6. De Maeyer EM. Prevention and controlling iron deficiency anaemia through primary health care. Geneva: World Health Organisation, 1999.

7. Gregory P, Taslim A. Health status of Pakistani population: a health profile and comparison with the United States. Am J Public Health. 2001;91:93-8.

8. Baker PN. Medical diseases complicating pregnancy. Obstetrics by Ten Teachers. $18^{\text {th }}$ edition. Hodder Arnold; 2006;15:179-99.

9. Marhatta R. Study of anemia in pregnancy and its outcome in Nepal Medical College Teaching Hospital, Kathmandu, Nepal. Nepal Med Coll J. 2007;9:270-4.

10. Levy A, Frayer D. Maternal anaemia during pregnancy. Eu J Obstet Reprod Biol. 2004;122(20):182-6.
11. Kavle JA. Maternal anemia and blood loss at child birth and postpartum in Zanzibar, Tanzania. Baltimore, MD: Bloomberg School of Public Health, Johns Hopkins University; 2005:204.

12. Karaflahin E, Ceyhan ST, Goktolga U, Keskin U, Bafler S. Maternal anemia and perinatal outcome. Perinatal J. 2007;15(3):129.

13. Ali AA, Dam I. Anaemia and stillbirth in Kassala hospital, Eastern Sudan. J Trop Pediatr. 2011;57(1):62-4.

14. Ali AA, Rayis DA. Severe anaemia is associated with a higher risk for preeclampsia and poor perinatal outcomes. BMC Research Notes. 2011;4:311.

15. Preeti J, Kural M. Maternal and foetal outcome in cases of severe Anaemia with pregnancy in rural setup. Int J Med Applied Sci. 2013;2(3):318.

Cite this article as: Yadav P. Severe anemia and adverse pregnancy outcome in a tertiary care hospital in North India. Int J Reprod Contracept Obstet Gynecol 2018;7:483-6. 